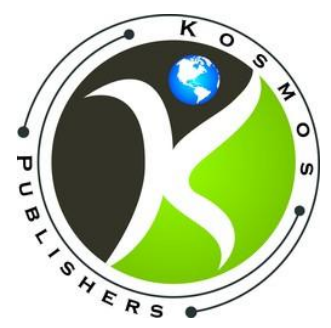

www.kosmospublishers.com

contact@kosmospublishers.com

DOI: 10.37722/AAHAE.2021601

\title{
Predicted Seasonal Development of Phytophagous Forest Insects in the Temperate Zone
}

\author{
Valentyna Meshkova* \\ Ukrainian Research Institute of Forestry \& Forest Melioration named after G. M. Vysotsky, Pushkinska \\ str. 86, Kharkiv, 61024, Ukraine
}

Received Date: August 29, 2021; Accepted Date: September 04, 2021; Published Date: September 10, 2021;

"Corresponding author: Valentyna Meshkova, Ukrainian Research Institute of Forestry \& Forest Melioration named after G. M. Vysotsky, Pushkinska str. 86, Kharkiv, 61024, Ukraine. Email: Valentynameshkova@ gmail.com

\begin{abstract}
In temperate climates, insects survive the winter in a coldinvulnerable stage. The timing of individual stages of insects is influenced by temperature (which will increase with climate change) and the photoperiod (which will remain unchanged). Therefore, the mechanical application of the sums of temperatures will not make it possible to predict the seasonal development of insects in the event of climate change.
\end{abstract}

The aim of this paper was to assess a possible shift of the development of forest phytophagous insects with different types of seasonal development under climate change. Calculations are made for foliage-browsing insects in Kharkiv region (northeastern part of Ukraine). Temperature data were taken from archives and predicted temperature from reference. Our classification of foliage browsing insects by the types of seasonal development considering voltinism, hibernating stage, and summer diapause was used. The deadlines for the development of individual stages of insects were analyzed considering the type of seasonal development, the deadlines of the appearance after hibernation, and the termination of active development in autumn. The dependences of insect development from temperature were used.

Analysis shows that the changes in the timing and rate of development of phytophages will depend on the type of seasonal development. Phytophagous species of the temperate zone, which are now monovoltine throughout the range, will remain so after global warming. Foliage-browsing species will accelerate the development of spring and early summer stages (before the summer solstice) and slow down the development of late summer and autumn stages, which will ensure the wintering of the most protected individuals. Foliage-browsing species capable of bivoltinous development within the current range will maintain this trend, but a further increase in the number of generations will be hindered by the photoperiodic response. Xylophages capable of bivoltine and multivoltine development can increase the number of generations. At the same time, due to the uneven development of insects in different parts of the tree and the stand, some individuals will hibernate in a stage that cannot withstand the cold.

Keywords: Air temperature; Climate change; Foliage browsing insects; Photoperiod; Rate of development; xylophags

\section{Introduction}

In temperate climates, insects survive the winter in a coldinvulnerable stage. The timing of individual stages of insects is influenced by temperature (which will increase with climate change) and the photoperiod (which will remain unchanged) $[1,2]$.

A measure of the amount of heat that a poikilothermic organism receives over a period of time is the sum of the air temperatures [2]. This parameter is calculated as the sum of the differences between the average daily air temperature and 
the temperature threshold (the minimum value of the temperature at which the development of this organism can occur).

Parameters of the temperature threshold and the sum of effective temperatures are widely used in the analysis of various populations, their adaptations to local environmental conditions, and forecasting the timing of individuals at different stages of development $[\mathbf{1 , 3}$.

So, knowing the values of the sums of temperatures necessary for the development of one generation of a multivoltine insect, it is possible to calculate the maximum possible number of generations in different years for different regions [1]. At the same time, the calculated number of generations often exceeds the actual one [4]. This is due to the fact that both the sum of temperatures and the threshold for the development of insects are not constant both for populations of the same species and for different generations of the same population. One of the reasons for this is the dependence of the life cycles of insects on the photoperiod $[2,5]$. So, in a temperate climate, where spring, summer, autumn, and winter replace each other, phytophagous insects have adapted to survive cold periods or periods with a lack of suitable food (sometimes in the second half of summer) in the most resistant stage (often in diapause) and in the most protected location [6]. Different species hibernate at different stages and complete development after winter at such times that the appearance of the feeding stage coincides with the availability of the most favorable food [7]. A signal for the acceleration or deceleration of development, in order to ensure timely entry into such a stage, is a certain value of the length of the day - the photoperiod $[1,2]$.

Therefore, for forest insects that begin development in early spring or complete in late autumn, the rule of sums of temperatures is often not very useful [8]. In spring, the starting point is close to the start of the growing season of forage species [9]. Key dates for determining intervals with a different approach to predicting the life cycle of phytophagous insects are dates of the stable transition of temperature over 0 , $5,10,15^{\circ} \mathrm{C}$ in spring (D0s, D5s, D10s, D15s) and below these limits in autumn (D0au, D5au, D10au, D15au), as these dates separate the phenological seasons of the year [8]. So the spring starts after D0s, summer lasts between D15s and D15au, autumn between D15au and D0au. Deadlines for the thawing of the soil, sap flow (D5s), budburst (D10s), and the development of insects are dedicated to these dates.

On the examples of insects with different types of seasonal development, it was shown that probability, severity, duration of outbreaks and intervals as well as intervals between them are related to the features of seasonal development of foliage browsing insects $[\mathbf{1 0}, 11]$. The dates and temperature thresholds and sums were estimated also for stem pests in different regions, particularly in Ukraine [12-14]. Comparison data on seasonal development of these insects in different regions allows suggesting some consequences of climate warming.
The aim of this paper was to assess a possible shift of development of forest phytophagous insects with different types of seasonal development under climate change.

\section{Methods}

All calculations were made with respect to common foliage-browsing insects with different types of seasonal development that damage oak (Quercus robur L.) and pine (Pinus sylvestris L.) в Kharkiv region, which is located in the northeastern part of Ukraine on the border of the forest-steppe and steppe $\left(50^{\circ} 00\right.$ ' $\left.\mathrm{N}, 36^{\circ} 10^{\prime} \mathrm{E}\right)$.

The temperature of particular months was taken from archives since 1894 and since 2005 from website https://rp5.ua. Actual dates of temperature transition over and below different limits were evaluated by our approach [8]. Predicted monthly temperature and the dates of temperature transition over and below different limits for 2021-2050 were taken from [15] (Fig. 1).

Data on the timing of the seasonal development of these insects and the dependence of the rates of development of different stages on temperature (Fig. 1) (the so-called phenological curves) are taken from our publications $[\mathbf{8 , 1 1 ]}$.

In analysis, classification of foliage browsing insects by the types of seasonal development considering voltinism, hibernating stage, and summer diapause was used [8].

In accordance with this classification [8], foliage browsing insects were divided into groups by hibernating stage: group 1 - egg hibernates (larvae feeding in spring), group 2 - larva hibernates (feeding in spring and at the end of vegetation, for example, Euproctis chrysorrhoea (Linnaeus, 1758) and Dendrolimus pini (Linnaeus, 1758)), group 3 - pupa hibernates (larvae feeding in spring or in summer-autumn). Members of groups 1-3 are monovoltine throughout the entire range, and the members of group 4 have a possibility of multivoltine development with diapausing eonymph (Diprion pini (Linnaeus, 1758)). Subgroups differ by the presence of summer diapause: subgroup 1a - summer diapause of eggs transits to winter diapause (Tortrix viridana (Linnaeus, 1758), Lymantria dispar (Linnaeus, 1758)); subgroup 1b - summer diapause of pupae or eonymph, swarming in autumn, winter diapause of eggs (Operophtera brumata (Linnaeus, 1758), Neodiprion sertifer (Geoffroy, 1785); subgroup 3a - summer diapause of pupae transits to winter diapause (Panolis flammea (Denis \& Schiff., 1775)); subgroup 3b - winter diapause of pupae transits to summer diapause (Bupalus piniarius (Linnaeus, 1758)).

The deadlines for the development of individual stages of insects were analyzed taking into account the type of seasonal development, the deadlines of the appearance after hibernation, and termination of active development in autumn.

When calculating the deadlines for the development of stages, which appeared after the end of hibernation, the 
evaluated dependences of their duration from temperature were used (see Fig. 1).

\section{Results and Discussion}

The top row of Fig. 1 shows a series of so-called phenological curves for insects hibernating at the egg stage Operophtera brumata, Tortrix viridana, and Lymantria dispar. All three species are characterized by a higher location of the phenological curve of caterpillar development compared to the phenological curve of spring egg development. That is, at the same temperature, the development of caterpillars of these species takes longer than the development of eggs. As noted above, it is not possible to determine the dependence of the duration of the full period of egg development (including the autumn and winter stages) on temperature.

It is also not possible to construct a phenological curve for the development of the pupae of Operophtera brumata, since the timing of the emergence of moths of this species is determined by the geographical coordinates of the area and is regulated by a photoperiodic reaction. It is impossible to construct phenological curves of caterpillar development for Euproctis chrysorrhoea and Dendrolimus pini, since these species overwinter at the caterpillar stage. For Diprion pini, the phenological curve of the development of pupae (more precisely, individuals in a cocoon - eonymphs, pronymphs and pupae) can only be constructed for individuals of the spring generation, since individuals of the autumn generation, after the end of the feeding, descend from the crowns into the forest litter, where they diapause and hibernate.

Comparison of phenological curves of pupal development shows that for species overwintering at the egg stage (Tortrix viridana and Lymantria dispar), phenological curves of pupal development on the graph are located higher than the curves of egg development and lower than the curves of caterpillar development (see Fig. 1).

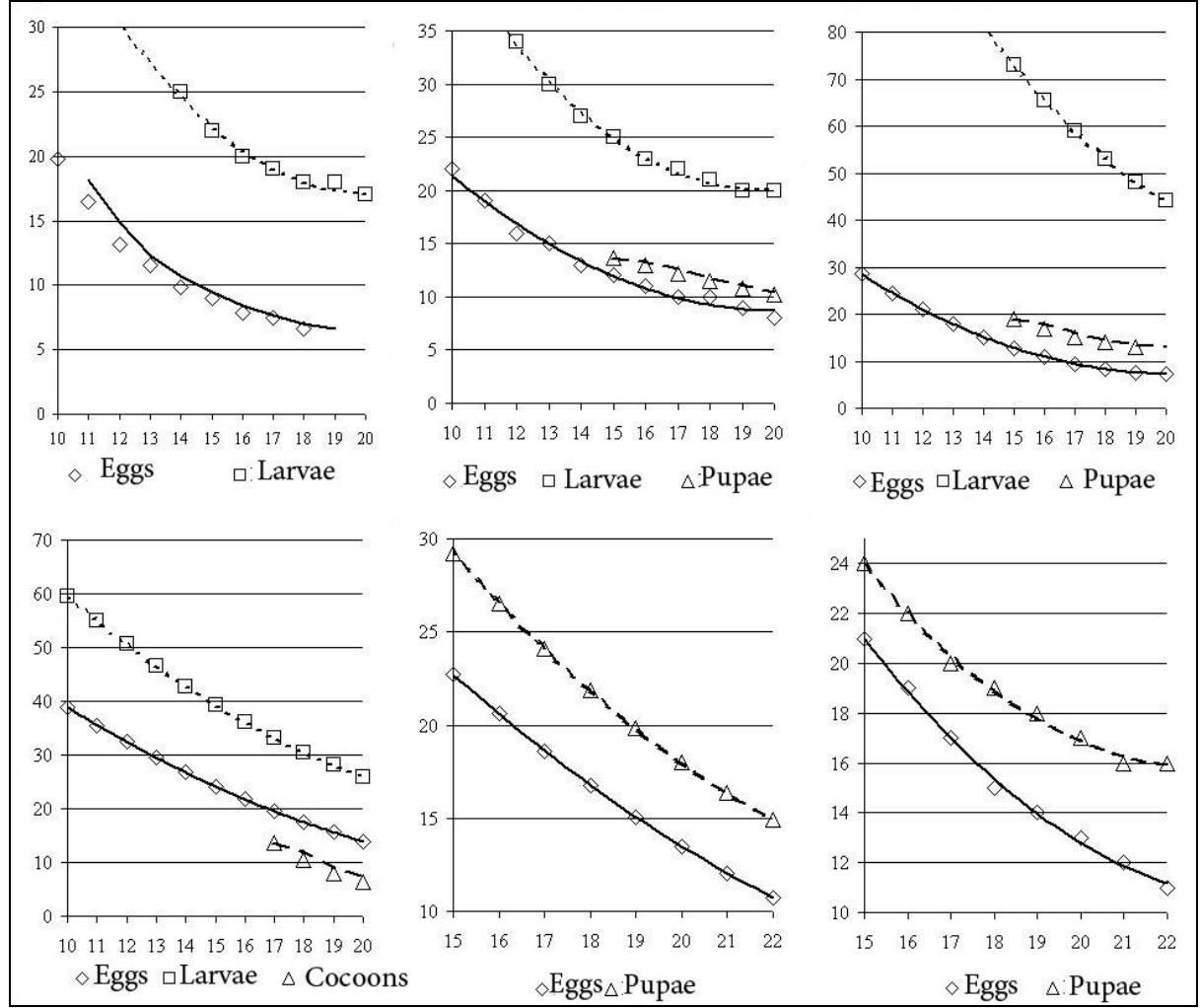

Figure 1: Dependence of duration of insect development (axis $\mathrm{Y}$, days) in different stages on air temperature (axis $\mathrm{X}$, ${ }^{\circ} \mathrm{C}$ ) (so-called phenological curves): upper row from left to right: Operophtera brumata, Tortrix viridana, Lymantria dispar; lower row from left to right: Diprion pini, Euproctis chrysorrhoea, Dendrolimus pini [8].

For species hibernating at the caterpillar stage (Euproctis chrysorrhoea and Dendrolimus pini), phenological curves of pupal development are also located higher than curves of egg development. That is, at the same temperature, pupae of these species develop longer than eggs.

The analysis of meteorological data indicates a tendency towards an increase in temperature in all months (Table 1). At the same time, in some years of the analyzed period, the temperature of individual months exceeded the predicted values. This means that phytophagous insects were able to adapt to predicted climate changes.

The largest increase in temperature is predicted in February and March (by 3.3 and $3.7^{\circ} \mathrm{C}$, respectively), the smallest in May and June (Table 1). The increase in 
temperature in February and March is reflected at the start of the growing season (Fig. 2), which contributes to an increase in the growing season (Fig. 3). To a lesser extent, this was facilitated by an increase in the temperature of August and autumn months. So the date of snow melting will shift from March 17 to March 9, the beginning of soil thawing - from
April 1 to March 25, active vegetation of trees from April 23 to April 18. Autumn natural phenomena will shift in the opposite direction: stable transition of temperature below $15{ }^{\circ} \mathrm{C}$ from September 10 to September 17, D10au from September 30 to October 17, D5au from October 26 to October 29, and D0au from November 27 to December 4.

\begin{tabular}{|c|c|c|c|c|c|c|}
\hline \multirow{3}{*}{ Months } & \multicolumn{6}{|c|}{ Temperature, ${ }^{\circ} \mathrm{C}$} \\
\hline & \multicolumn{4}{|c|}{ Current } & \multirow{2}{*}{ Predicted* } & \multirow{2}{*}{ Difference } \\
\hline & current & $\pm \mathrm{SE}$ & $\min$ & $\max$ & & \\
\hline January & -6.63 & 0.35 & -15.50 & -1.00 & -3.66 & 2.97 \\
\hline February & -6.16 & 0.37 & -16.40 & 1.10 & -2.86 & 3.30 \\
\hline March & -0.97 & 0.27 & -7.40 & 5.20 & 2.68 & 3.66 \\
\hline April & 8.16 & 0.23 & 2.00 & 13.60 & 10.00 & 1.85 \\
\hline May & 15.46 & 0.20 & 11.20 & 20.10 & 15.86 & 0.40 \\
\hline June & 19.03 & 0.19 & 15.40 & 24.40 & 19.90 & 0.87 \\
\hline July & 20.69 & 0.16 & 17.30 & 25.40 & 22.30 & 1.61 \\
\hline August & 19.54 & 0.16 & 16.40 & 24.70 & 21.34 & 1.80 \\
\hline September & 13.79 & 0.17 & 10.20 & 19.10 & 15.07 & 1.28 \\
\hline October & 7.16 & 0.21 & 1.30 & 12.20 & 8.62 & 1.46 \\
\hline November & 1.02 & 0.26 & -7.60 & 9.90 & 2.38 & 1.37 \\
\hline December & -4.09 & 0.28 & -10.90 & 2.90 & -2.90 & 1.19 \\
\hline \multicolumn{7}{|c|}{ * - by modified A1B climate change scenario [15] } \\
\hline
\end{tabular}

Table 1: Current and predicted air temperature for Kharkiv.

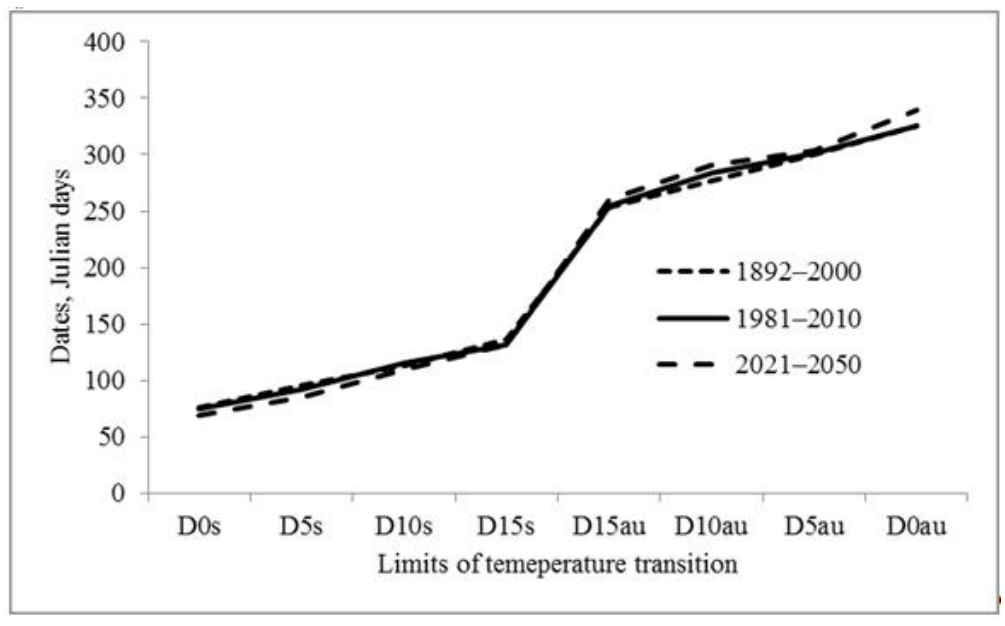

Figure 2: Shift in the dates of stable transition of air temperature above $0,5,10$ and $15^{\circ} \mathrm{C}$ in spring (D0s, D5s, D10s, D15s) and below these limits in autumn (D15au, D10au, D5au, D0au) (Kharkiv meteorological station, 1892-2000 and 1981-2010 - evaluated according to archival data;2021-2050 - predicted from modified A1B climate change scenario [15]. 


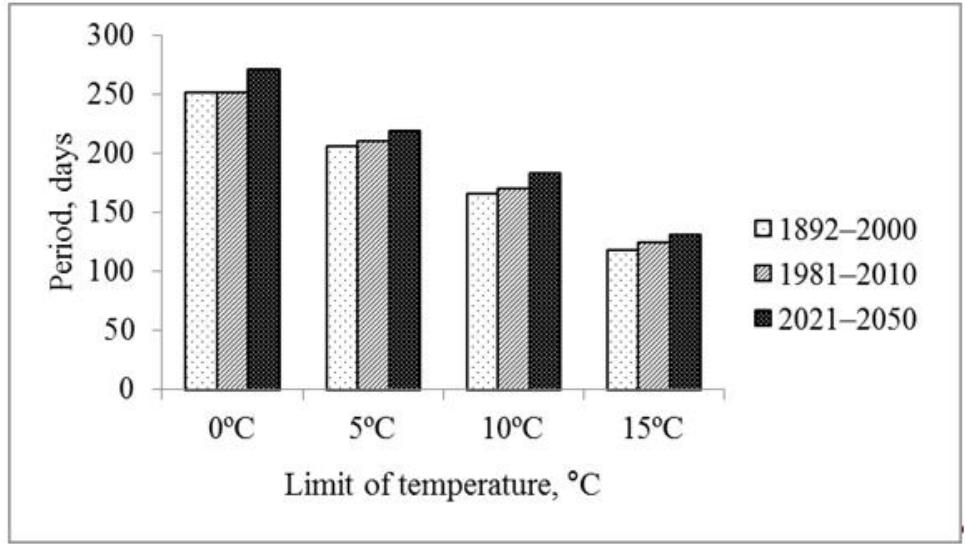

Figure 3: Duration of periods with air temperature above $0,5,10$ and $15^{\circ} \mathrm{C}$ (Kharkiv meteorological station, 1892-2000 and $1981-$ 2010 - evaluated according to archival data; 2021-2050 - predicted from modified A1B climate change scenario [15].

The date of hatching the species of phenological group 1 and the renewal of active feeding of the larvae of phenological group 2 approximately corresponds to D10s and will correspond to it with a change in climate since only in this case the maximum coincidence of the time of appearance of the larvae and the required food (foliage) will be ensured [8].

The development of larvae of phenological group 1 from hatching to pupation depends on temperature (see Fig. 1).
With the expected earlier transition D0s and higher May temperature, pupation and swarming of group 1a will occur earlier. The feeding period will become shorter. Pupation of larvae of phenological group $1 \mathrm{~b}$ will also occur earlier (Table 2). The consequence of this for the species of phenological groups $1 \mathrm{a}$ and $1 \mathrm{~b}$ may be a decrease in the size of pupae and the fecundity of adults [16].

\begin{tabular}{|c|c|c|c|c|c|}
\hline Scenario & Egg (beginning of the year) & Larva & Pupa & Adult & Egg (end of the year) \\
\hline Current & 113 & 30 & 15 & 10 & 197 \\
\hline Predicted & 108 & 20 & 12 & 8 & 217 \\
\hline
\end{tabular}

Table: 2 Current and predicted duration (days) of different stages of phytophags of Tortrix viridana (group 1a).

At the same time, regardless of the timing of the completion of larvae feeding of phenological group $1 \mathrm{~b}$, the adults will not become earlier, since its timing is determined by the photoperiodic response which depends on the geographical coordinates of the point. Particularly, adults of Neodiprion sertifer appear after D15au, and of Operophtera brumata after D10au. That is, the swarming of these species in the east occurs earlier than in the west, and earlier in the north than in the south. Since these species hibernate at the egg stage, the adults appear late enough so that the laid eggs do not hatch in the absence of food. Since the autumn transition of temperature will be shifted to later dates, individuals with the latest swarming will gain advantages.

The viability of species with $1 \mathrm{a}$ and $1 \mathrm{~b}$ type of seasonal development is most dependent on the timing of the appearance of available food and parasitoids. The development of buds of deciduous trees begins after thawing of the soil, that is, after about D5s, and parasitoids emerge later since they must undergo maturation feeding on flowering plants [8]. The shifts of D5s and D10s will determine the degree of synchronicity in the development of larvae and foliage of the host plant.

The timing of the end of pupae development and the beginning of swarming of Operophtera brumata (1b phenological group) also do not depend on the rates of development of the previous stages. These dates coincide with the dates of the end of the growing season (the dates of a stable transition of air temperature in the fall through $5^{\circ} \mathrm{C}$ ), the average time of which depends on the longitude and latitude of the location. So D5au is October 24 in Kharkiv, October 31 in Lviv, and November 20 in Symferopol [8]. That is, the swarming of Operophtera brumata occurs first of all in the east of Ukraine, later in the west, and last of all in the south.

Thus, the time at the stage of the egg and larva of the species of group $1 \mathrm{~b}$ will decrease, and at the stage of the eonymph or pupa, it will increase (Table 3 ).

\begin{tabular}{|c|c|c|c|c|c|}
\hline Scenario & Egg (beginning of the year) & Larva & Eonymph & Adult & Egg (end of the year) \\
\hline Current & 113 & 36 & 104 & 12 & 100 \\
\hline Predicted & 99 & 31 & 137 & 10 & 88 \\
\hline
\end{tabular}

Table: 3 Current and predicted duration (days) of different stages of Neodiprion sertifer (group 1b). 
Species of phenological group 2 hibernate as larvae of different ages with 2 feeding periods (Table 4). The beginning of the first and the end of the second period depend on the availability of available food - the budburst for deciduous trees and the beginning of the active vegetation of conifers. The spring period begins at D10s, and the autumn period ends at D10au.

\begin{tabular}{|c|c|c|c|c|c|c|c|}
\hline Scenario & $\begin{array}{c}\text { Larva } \\
\text { hybernates }\end{array}$ & $\begin{array}{c}\text { Larva } \\
\text { feeds }\end{array}$ & Pupa & Adult & Egg & Larva feeds & Larva hybernates \\
\hline Current & 113 & 45 & 18 & 10 & 14 & 53 & 112 \\
\hline Predicted & 99 & 61 & 16 & 9 & 13 & 83 & 84 \\
\hline
\end{tabular}

Table: 4 Current and predicted duration (days) of different stages of Dendrolimus pini (group 2).

Pupae, adults, and eggs of species of phenological group 2 develop in summer on close dates in different regions, because these dates are closed to the summer solstice. Some part of larvae which late in development stop this process and resume it simultaneously with the appearance of larvae a new generation in August. The age composition of hibernating Dendrolimus pini is very diverse (from 2 nd to 6 th instars). One part of the population completes its development for one year and another for two years.

For species overwintering at the larvae stage, it is impossible to determine the dependence of the development rate of individuals on temperature. On the one hand, this is due to the fact that the winter diapause of larvae can occur at different ages: for the Dendrolimus pini in any instar, except for the first one [17]. On the other hand, in species overwintering at the larvae stage, the development of overwintered individuals before pupation occurs in the spring and in the first half of summer, while young larvae hatch in the second half of summer and feed up to early autumn.
The dependence of larvae development rate from the temperature is absent at high temperatures and long days.

Panolis flammea hibernates as pupa, and its summer diapause transits to winter diapause. Attempts to evaluate the dependence of the rate of spring development of pupae from temperature turned out to be unsuccessful [8]. Most accurately it is possible to predict the time of emergence of moths of this species by the date of stable transition of air temperature through $5{ }^{\circ} \mathrm{C}$, which approximately corresponds to the date of thawing of the upper layers of the soil. Such adaptation makes it possible to synchronize the appearance of larvae with the availability of the most preferred food, for example, young pine needles for Panolis flammea.

With an increase in temperature, the spring development of eggs and larvae of Panolis flammea will occur faster, and the summer-autumn stay in the pupal stage will be lengthened, which will ensure timely emergence of adults and hatching of larvae in the spring, just at the same time as the emergence of young pine shoots (Table 5).

\begin{tabular}{|c|c|c|c|c|}
\hline Scenario & Pupa (hybernating) & Adult + Egg & Larva & Pupae (summer-autumn) \\
\hline Current & 98 & 30 & 25 & 212 \\
\hline Predicted & 85 & 24 & 18 & 238 \\
\hline
\end{tabular}

Table: 5 Current and predicted duration (days) of different stages of Panolis flammea (group 3a).

Pupation of Panolis flammea occurs almost at the same time as for representatives of group 1a, but the pupa stops developing until the next spring. The signal for the beginning of their development is soil thawing and D5s, which are predicted to occur earlier. As in the species of group $1 \mathrm{a}$ and $1 \mathrm{~b}$, the development time of larvae of group $3 \mathrm{a}$ will be reduced, which can negatively affect the size of pupae and the fertility of adults [16], and, in addition, their survival during a long stay in the forest litter will decrease, particularly at high summer temperature [18].

As for species of groups $1 \mathrm{a}$ and $1 \mathrm{~b}$, the viability of individuals of group $3 \mathrm{a}$ depends on synchronization with the spring development of parasitoids hibernating in the forest litter [8]. Since pupae of these species spend 9-10 months in the litter, their drying may increase with increasing temperature.
The dates of swarming for Bupalus piniarius (group3b) are close to the dates of the summer solstice [8]. Its adults lay eggs on the previous year's foliage the next day after hatching. Only in a case of high population density or severe damage to old foliage they lay eggs on the foliage of the current year, which growth is still continuing at this time. Larvae feed until autumn, and after D15au the larvae gradually descend into the forest litter. There, the larvae of the last instar pupate, and younger ones often die. With an increase in the duration of the D15s - D15au period, the proportion of caterpillars with successful completion of development will increase. As the temperature rises, the development of eggs is accelerated, but the period of development of the larvae is lengthened (Table 6). 


\begin{tabular}{|c|c|c|c|c|}
\hline Scenario & Pupa (hybernating) & Adult + Egg & Larva & Pupa (summer-autumn) \\
\hline Current & 173 & 37 & 82 & 73 \\
\hline Predicted & 173 & 28 & 90 & 74 \\
\hline
\end{tabular}

Table: 6 Current and predicted duration (days) of different stages of Bupalus piniaria (group 3b).

Since hatching of the Bupalus piniarius larvae coincides with the period of the longest day, the temperature determines the rate of development of only young caterpillars, and from the end of July, under the influence of a photoperiodic reaction, the rate of development of caterpillars changes in such a way that pupation of caterpillars occurs at the end of the growing season. That is why the duration of development of the pine moth caterpillars, noted in different regions, ranges from 77 [19] to 95 [20] days.

The representative of group 4 (Diprion pini) is the only common foliage browsing species capable of having 2 generations a year (spring and autumn), and sometimes an additional intermediate generation (summer generation) initiated by individuals emerging from diapausing cocoons. The emergence of adults from overwintered cocoons occurs at about D10s. The larvae of the spring generation feed in June, and those of the autumn generation feed in August, until about D15au.

In the southern regions and in warm years the development of Diprion pini is bivoltine. In northern regions and in cold years, depending on the combination of photoperiod and temperature by the time of cocooning, the specimens of Diprion pini develop according to one of the following options:

- monovoltine1 - eonymphs in cocoons enter diapause for several years, and adults appear in spring;

- monovoltine $1 \mathrm{a}$ - the sawfly completes summer diapause simultaneously with the appearance of the autumn generation;

- monovoltine 2 -only the autumn generation develops without the spring one $[8,21]$ (Table 7 ).

\begin{tabular}{|c|c|c|c|c|c|c|c|c|c|}
\hline \multirow{2}{*}{ Scenario } & \multicolumn{4}{|c|}{ Spring } & \multicolumn{4}{c|}{ Summer } & Autumn \\
\cline { 2 - 10 } & Cocoon & Adult & Egg & Larva & Cocoon & Adult & Egg & Larva & Cocoon \\
\hline Bivoltine & 113 & 7 & 29 & 21 & 16 & 7 & 20 & 40 & 112 \\
\hline Monovoltine 1 & 113 & 7 & 29 & 28 & 188 & - & - & - & - \\
\hline Monovoltine 1a & 113 & 10 & 29 & 21 & 40 & - & - & 40 & 112 \\
\hline Monovoltine 2 & 184 & - & - & - & - & 8 & 20 & 41 & 112 \\
\hline
\end{tabular}

Table: 7 Possible duration (days) of different stages of Diprion pini (group 4).

With an increase in the duration of the growing season (D10s - D10au) and an increase in temperature, the bivoltine development of Diprion pini will dominate. A further increase in the number of generations of this species is impossible due to its photoperiodic reaction.

The development of xylophages inhabiting living trees is also confined to the phenological periods of the development of nature and host species, primarily to the dates of the beginning of active vegetation (D10s) (Table 8). The dates of the beginning of swarming may depend on the stage of hibernating and its location (in the wood, under the bark, in the litter). With an increase in temperature, the larvae can complete development earlier to the pupa and adult (Monochamus galloprovincialis (Olivier, 1795)), and adults either undergo maturation feeding by phloem under the bark (Acanthocinus aedilis (Linnaeus, 1758)) or in the shoots (Tomicus minor (Hartig, 1834) and Tomicus piniperda (Linnaeus, 1758)). We revealed hibernation of Ips acuminatus (Gyllenhal, 1827) and Ips sexdentatus (Borner, 1776) as larvae and adult, and the first of them also as pupae. The last two species usually have 2 generations per year with additional sister broods but sometimes they have 1 or 3 generations.
So the common foliage browsing and xylophagous insects, living in the forests of Ukraine after warming will not change the development cycles, but they can change the timing and duration of their individual parts.

Species hibernating at the egg stage (1a and $1 \mathrm{~b}$ ) will hatch when preferred food is available. Since the timing of the beginning of the growing season of trees depends on the timing of soil thawing, the synchronicity in the appearance of phytophagous larvae and leaves may be disrupted [9]. If the leaves begin to develop before the larvae appear, by the time the larvae hatch they will contain less nitrogen and more protective substances. Acceleration of larval development at elevated temperatures will lead to a decrease in the size of pupae and the fertility of adults [16]. Also, the development of these species is affected by synchronicity with entomophages hibernating in the litter, which need to undergo maturation feeding and be ready to hit the vulnerable stage of the phytophage [22, 23].

For species hibernating at the larvae stage, synchronicity with food and entomophages is less important; however, at high temperatures, the semivoltine species (Dendrolimus pini) will become monovoltine [17]. For the survival of species that 
hibernate at the pupal stage and begin feeding on young foliage (Panolis flammea), their synchronization with food and entomophages is important, as well as the possibility of pupae drying out during their stay in the litter in the summer months [17]. Species of groups $1 \mathrm{a}$ and $3 \mathrm{a}$ complete development before the hibernating stage (egg and pupa, respectively) at a time depending on the beginning of spring development and the sum of temperatures.

In accordance with the photoperiodic reactions, the timing of the end of the feeding of the larvae of group 2, 3a and the autumn generation of the larvae of group 4 correspond to the date of the stable transition of air temperature through $15^{\circ} \mathrm{C}$ (D15au). The swarming of adults of the species of group 1a, hibernating at the egg stage, occurs approximately at D15au for Neodiprion sertifer and D5au for Operophtera brumata. Since the dates of these phenomena are due to the photoperiodic reaction and depend on the latitude and longitude of the area, in the case of an increase in temperature, the success of phytophagous insects depends on the time of their adaptation. So, if the adult of Neodiprion sertifer lays eggs in the foliage with still active vegetating, the eggs can be flooded with resin. There is also a risk of larvae appear in autumn, which will not be able to survive.

Among the xylophages inhabiting living trees, the majority are also monovoltine (Table 8). In the forests of Ukraine, the multivoltine species are Ips acuminatus, Ips sexdentatus, Orthotomicus sp., and Ips typographus (Linnaeus, 1758), which can increase the number of generations under favorable conditions. Thus, I. acuminatus has one generation per year in Scandinavia [24], and two or three with sister broods in Southern Europe [25, 26]. Some xylophages can stop development for several years under unfavorable conditions, in particular, Monochamus galloprovincialis in a dry substrate [14].

\begin{tabular}{|c|c|c|c|c|c|}
\hline Species & Gene-ration & $\begin{array}{c}\text { Hibernating } \\
\text { stage }\end{array}$ & $\begin{array}{c}\text { Swarmi } \\
\text { ng }\end{array}$ & $\begin{array}{c}\text { Months of larvae } \\
\text { feeding }\end{array}$ & $\begin{array}{c}\text { Months of } \\
\text { young adults }\end{array}$ \\
\hline $\begin{array}{c}\text { Monochamus } \\
\text { galloprovincialis (Olivier, } \\
\text { 1795) }\end{array}$ & 1 year & Larvae & D10s & $\begin{array}{c}\text { IV-V } \\
\text { VII-D10au }\end{array}$ & VI \\
\hline $\begin{array}{c}\text { Acanthocinus aedilis } \\
\text { (Linnaeus, 1758) }\end{array}$ & 1 year & Adult & D10s & V-VIII & VIII \\
\hline $\begin{array}{c}\text { Tomicus minor (Hartig, } \\
\text { 1834) } \\
\end{array}$ & 1 year & Adult & D10s & $\mathrm{V}$ & $\mathrm{VI}^{*}$ \\
\hline $\begin{array}{c}\text { Tomicus piniperda } \\
\text { (Linnaeus, 1758) }\end{array}$ & 1 year & Adult & D5s & $\mathrm{V}$ & VI* \\
\hline $\begin{array}{c}\text { Ips acuminatus } \\
\text { (Gyllenhal, 1827) }\end{array}$ & $\begin{array}{l}1-3 / \text { year }+ \\
\text { sister broods }\end{array}$ & $\begin{array}{c}\text { Larvae, Pupae, } \\
\text { Adult }\end{array}$ & D10s & V-IX & $\mathrm{VI}-\mathrm{X}^{* *}$ \\
\hline $\begin{array}{c}\text { Ips sexdentatus (Borner, } \\
\text { 1776) }\end{array}$ & $\begin{array}{c}1-3 / \text { year }+ \\
\text { sister broods }\end{array}$ & Larvae, Adult & D10s & $\mathrm{V}-\mathrm{IX}$ & $\mathrm{VI}-\mathrm{X}^{* *}$ \\
\hline
\end{tabular}

Table: 8 Patterns of seasonal development for xylophagous insects.

Most of xylophages are monovoltine at different points of the range and hibernate at the larval or imago stage, with the larvae going deep into the wood before hibernation, and the adults are located under the bark, in the galleries, in shoots [27], or in the forest litter [25]. Hibernation of pupae is reported for I. acuminatus [13] and I. typographus [4], however, this stage is most vulnerable to low temperatures, however, this stage is the most vulnerable to low temperature as well as to predation. Since climate change occurs gradually, a rapid increase in the synchronization of the development of phytophages and foliage of the host plant, as well as entomophages and phytophages, can be expected. If it is impossible to quickly adapt or die out of the host plant, insect species capable of polyphagia and migration to places with the presence of a preferred plant will benefit.

Location of individual stages of insects may be changed. So Tomicus piniperda in the forest zone hibernates under the bark in the lower part of the stem, and in the forest-steppe zone - in the forest litter or in the shoots in the crown, where these beetles underwent maturation feeding [27].

\section{Conclusions}

The changes in the timing and rate of development of phytophages will depend on the type of seasonal development. Phytophagous species of the temperate zone, which are now monovoltine throughout the range, will remain so after global warming. Foliage-browsing species will accelerate the development of spring and early summer stages (before the summer solstice) and slow down the development of late summer and autumn stages, which will ensure the wintering of the most protected individuals. Foliage-browsing species capable of bivoltinous development within the current range will maintain this trend, but a further increase in the number of generations will be hindered by the photoperiodic response. Xylophages capable of bivoltine and multivoltine development can increase the number of generations. At the same time, due to the uneven development of insects in different parts of the 
tree and the stand, some individuals will hibernate in a stage that cannot withstand the cold.

Therefore, the mechanical application of the sums of temperatures will not make it possible to predict the seasonal development of insects in the event of climate change. In the temperate climate zone, when predicting the seasonal development of insects, it is necessary to take into account the type of seasonal development of each species, namely the wintering stage, voltinism, and photoperiodic response.

\section{References}

1. Tauber MJ, Tauber CA, Masaki S (1986) Seasonal Adaptations of Insects. -Oxford University Press, New York, 411.

2. Saulich A Kh (1999) Seasonal development of insects and the possibilities of their dispersal. Sankt-Peterburg. 247. ISBN 5-288-02031-0.

3. Honek A, Kocourek F (1990) Temperature and development time in insects: a general relationship between thermal constants. Zoologische Jahrbucher. Abteilung fur Systematik, Okologie und Geographie der Tiere 117:401-439.

4. Štefková K, Okrouhlík J, Doležal P (2017) Development and survival of the spruce bark beetle, Ips typographus (Coleoptera: Curculionidae: Scolytinae) at low temperatures in the laboratory and the field. Eur. J. Entomol. 114:1-6.

5. Jactel H, Koricheva J, Castagneyrol B (2019) Responses of forest insect pests to climate change: not so simple. Current opinion in insect science. 35:103-108.

6. Tougeron K (2019) Diapause research in insects: historical review and recent work perspectives. Entomologia Experimentalis et Applicata 167:27-36.

7. Rosenblatt AE (2018) Shifts in plant nutrient content in combined warming and drought scenarios may alter reproductive fitness across trophic levels. Oikos 127:1853-1862.

8. Meshkova VL (2009) Seasonal development of foliage browsing insects. Novoe slovo: Kharkov, Ukraine, 396. ISBN 978-966-2046-69-4.

9. Lindén A (2018) Adaptive and nonadaptive changes in phenological synchrony. Proceedingsof the National Academy of Sciences 115:5057-5059.

10. Meshkova V (2002) Dependency of outbreaks distribution from insects-defoliators' seasonal development. In Proceedings--Ecology, Survey, and Management of Forest Insects: Kraków, Poland, September 1-5. No. 311. USDA Forest Service, Northeastern Research Station. McManus ML, Liebhold AM. (Eds.). 52-60.

11. Meshkova V (2002) Phenological prediction of forest pest defoliators // Ecology, Survey and Management of Forest Insects. In Proceedings--Ecology, Survey, and Management of Forest Insects: Kraków, Poland, September 1-5, No. 311. USDA Forest Service, Northeastern Research Station. McManus ML, Liebhold AM. (Eds.). 160-161.
12. Meshkova VL, Kochetova AI, Skrylnik YuYe, Zinchenko OV (2017) Seasonal development of the timberman beetle Acanthocinus aedilis (Linnaeus, 1758) (Coleoptera: Cerambycidae) in the North-Eastern Steppe of Ukraine. The Kharkov Entomol. Soc. Gaz. 25:40-44.

13. Meshkova VL, Kochetova AI, Zinchenko OV, Skrylnik YuYe (2017) Biology of multivoltine bark beetles species (Coleoptera: Scolytinae) in the North-Eastern Steppe of the Ukraine. The Bull. of Kharkiv National Agrarian University. Ser. Phytopatology and Entomology 1-2:117124.

14. Meshkova VL, Skrylnik YuYe, Zinchenko OV, Kochetova AI (2017) Seasonal development of the pine sawyer beetle (Monochamus galloprovincialis) in the north-eastern steppe of Ukraine. Forestry \& Forest Melioration 130:223-230.

15. Shvidenko A, Buksha I, Krakovska S (2018) Vulnerability of Ukrainian forests to climate change. Nika-Centr, Kyiv, Ukraine. 184. ISBN 978-966-521-7190 .

16. Gardner JL, Peters A, Kearney MR, Joseph L, Heinsohn $\mathrm{R}$ (2011) Declining body size: a third universal response to warming? Trends in ecology \& evolution 26:285-291.

17. Geispits KF (1965) Photoperiodic and temperature reactions determining the seasonal development of Dendrolimus pini L. and D. sibiricus Tschetw. (Lepidoptera, Lasiocampidae). Entomol. review 44:538553.

18. Mech AM, Tobin PC, Teskey RO, Rhea JR, Gandhi KJK (2018). Increases in summer temperatures decrease the survival of an invasive forest insect. Biological Invasions 20:365-374.

19. Palnikova EN, Sviderskaya IV, Sukhovolsky VG (2002) Pine moth in the forests of Siberia: Ecology, population dynamics, impact on plantations. - Novosibirsk: Nauka 232. ISBN 5-02-032018-8.

20. Martynova GG (1969) On the biology and ecology of the pine moth during the outbreak of mass reproduction (1960-1966). Problems of forest entomology. Moscow: MLTI:82-113.

21. Geri C, Goussard F (1988) Incidence de la photophase et de la temperature sur la diapause de Diprion pini L. (Hym. Diprionidae). J. Appl. Ent. 106:150-172.

22. Damien M, Tougeron K (2019) Prey-predator phenological mismatch under climate change. Current opinion in insect science 35:60-68.

23. Van Nouhuys S, Lei G (2004) Parasitoid-host metapopulation dynamics: the causes and consequences of phenological asynchrony. Journal of Animal Ecology 73:526-535.

24. Bakke A (1968) Ecological studies on bark beetles (Coleoptera: Scolytidae) associated with Scots pine (Pinus sylvestris L.) in Norway with particular reference to the influence of temperature. Medd Nor Skogforsk. 21:443-602.

25. Colombari F, Battisti A, Schroeder LM, Faccoli M (2012) Life-history traits promoting outbreaks of the pine bark beetle Ips acuminatus (Coleoptera: Curculionidae, 
Predicted Seasonal Development of Phytophagous Forest

\section{Insects in the Temperate Zone}

Scolytinae) in the south-eastern Alps. Eur J Forest Res. 131:553-561.

26. Faccoli M (2015) European bark and ambrosia beetles: types, characteristics and identification of mating systems.
Copyright: (C) 2021 Valentyna Meshkova*

WBA handbooks 5, Verona, Italy 160. ISBN 978-88903323-4-0.

27. Lieutier F, Battisti A (Eds.) (2004) Bark and wood boring insects in living trees in Europe: a synthesis. Kluwer Academic Publishers: Dordrecht, The Netherlands, 569.

Citation: Meshkova V (2021) Predicted Seasonal Development of Phytophagous Forest Insects in the Temperate Zone. Adv Agri Horti and Ento: AAHE-158. 